\title{
Nonlabens tegetincola gen. nov., sp. nov., a novel member of the family Flavobacteriaceae isolated from a microbial mat in a subtropical estuary
}

Correspondence Pei-Yuan Qian boqianpy@ust.hk

\author{
Stanley C. K. Lau, ${ }^{1}$ Mandy M. Y. Tsoi, ${ }^{1}$ Xiancui Li, ${ }^{1}$ Ioulia Plakhotnikova, ${ }^{1}$ \\ Sergey Dobretsov, ${ }^{1}$ Po-Keung Wong, ${ }^{2}$ Joseph R. Pawlik ${ }^{3}$ \\ and Pei-Yuan Qian ${ }^{1}$
}
${ }^{1}$ Coastal Marine Laboratory/Department of Biology, The Hong Kong University of Science and Technology, Clear Water Bay, Kowloon, Hong Kong SAR
${ }^{2}$ Department of Biology, The Chinese University of Hong Kong, Shatin, NT, Hong Kong SAR
${ }^{3}$ Center for Marine Science, University of North Carolina at Wilmington, Wilmington, NC, USA

\begin{abstract}
An orange-pigmented, Gram-negative, non-motile, rod-shaped, strictly aerobic bacterium (UST030701-324 $4^{\top}$ ) was isolated from a microbial mat in an estuary in the Bahamas. The DNA $\mathrm{G}+\mathrm{C}$ content was $33.6 \mathrm{~mol} \%$. Predominant fatty acids were $\mathrm{i} 15: 0, \mathrm{i} 16: 0, \mathrm{i} 17: 0 \mathrm{3}-\mathrm{OH}$, and summed feature 3 , comprising i15:0 2-OH and/or $16: 1 \omega 7 c$. MK-6 was the only respiratory quinone. Flexirubin-type pigments were not produced. Phylogenetic analysis based on $16 \mathrm{~S}$ rRNA gene sequences placed UST030701-324 ${ }^{\top}$ in a distinct lineage in the family Flavobacteriaceae with less than $90 \cdot 7 \%$ sequence similarity to the members of the nearest genus, Psychroflexus. UST030701-324 ${ }^{\top}$ can be distinguished from other members of Flavobacteriaceae by a number of chemotaxonomic and phenotypic characteristics. It is thus proposed that UST030701-324 ${ }^{\top}$ represents a novel taxon designated Nonlabens tegetincola gen. nov., sp. nov. The type strain is UST030701-324 $4^{\top}\left(=\right.$ NRRL B- $41136^{\top}=$ JCM $\left.12886^{\top}\right)$.
\end{abstract}

The family Flavobacteriaceae, belonging to the phylum Cytophaga-Flavobacterium-Bacteroides, accommodates a large number of marine bacteria that are either psychrophilic or psychrotolerant (Bernardet et al., 1996). Based on the data of the present study, we proposed the mesophilic bacterial strain UST030701-324 ${ }^{\mathrm{T}}$ of estuarine origin to represent a novel genus of the Flavobacteriaceae.

The bacterial strain UST030701-324 ${ }^{\mathrm{T}}$ was isolated from a microbial mat covering a polystyrene surface retrieved from an estuarine mangrove habitat in the Bahamas. After $48 \mathrm{~h}$ of cultivation at $30^{\circ} \mathrm{C}$ on an agar medium composed of $5 \mathrm{~g}$ peptone $1^{-1}, 3 \mathrm{~g}$ yeast extract $1^{-1}$ and $0 \cdot 22 \mu \mathrm{m}$-filteredseawater (referred to as marine agar hereafter), UST030701$324^{\mathrm{T}}$ appeared as orange, convex, circular colonies $(2-4 \mathrm{~mm}$ diameter) with smooth surfaces and entire translucent margins. No diffusible pigment was observed. Unless otherwise specified, all characteristics described hereafter were based on cultures grown on marine agar for $48 \mathrm{~h}$ at $30^{\circ} \mathrm{C}$.

The GenBank/EMBL/DDBJ accession number for the 16S rRNA gene sequence of strain UST030701-324 $4^{\top}$ is AY987349.

A scanning electron micrograph and detailed phenotypic characteristics of UST030701-324 $4^{\top}$ are available as supplementary material in IJSEM Online.
The optimum temperature for the growth of UST030701$324^{\mathrm{T}}$ was $28-36^{\circ} \mathrm{C}$.

The nearly complete $16 \mathrm{~S}$ rRNA gene sequence of UST030701-324 ${ }^{\mathrm{T}}$ (1462 bp) was obtained using a dye terminator method as described elsewhere (Lau et al., 2004). Comparison of the nearly complete $16 \mathrm{~S}$ rRNA gene sequence of UST030701-324 ${ }^{\mathrm{T}}$ to those available from GenBank revealed that UST030701-324 ${ }^{\mathrm{T}}$ was a member of the family Flavobacteriaceae. A neighbour-joining phylogenetic tree constructed using the ARB software package (Ludwig et al., 2004) showed that UST030701-324 ${ }^{\mathrm{T}}$ formed a clade together with several uncharacterized bacterial strains (93.6-94.6\% sequence similarity). This clade did not cluster robustly with any recognized species or genus (Fig. 1). UST030701-324 ${ }^{\mathrm{T}}$ was nearest to the members of the genera Psychroflexus and Salegentibacter, with $16 \mathrm{~S}$ rRNA gene sequence similarity ranging from $88 \cdot 5$ to $90 \cdot 7 \%$. Trees based on maximum-parsimony and maximumlikelihood methods showed essentially the same topology (Fig. 1). The results of phylogenetic analysis suggest that UST030701-324 ${ }^{\mathrm{T}}$ represents a novel genus within the family Flavobacteriaceae.

The DNA G + C content of UST030701-324 ${ }^{\mathrm{T}}$, determined by an HPLC method (Mesbah et al., 1989), was 


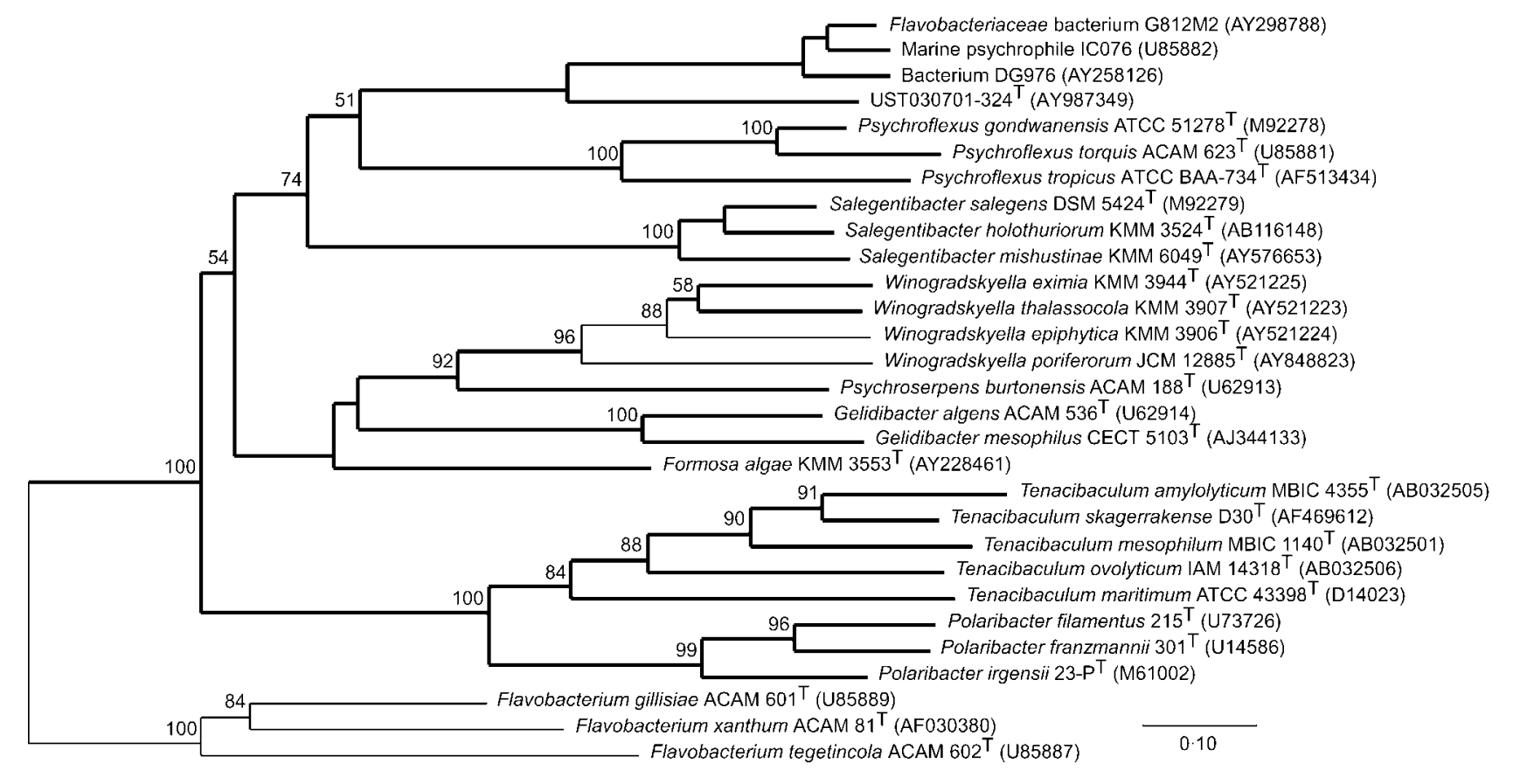

Fig. 1. Neighbour-joining dendrogram showing the estimated phylogenetic relationships among UST030701-324 ${ }^{\top}$ and related species on the basis of $16 \mathrm{~S}$ rRNA gene sequences. Strains belonging to the genus Flavobacterium serve as outgroups. Lines in bold type indicate branches also found in maximum-likelihood and parsimony trees. Scale bar represents 1 nucleotide substitution per 10 nucleotides. Bootstrap values $>50 \%$ (500 replicates) are indicated at nodes. GenBank accession numbers are shown in parentheses.

$33 \cdot 6 \pm 0 \cdot 3 \mathrm{~mol} \%$ (three replicates). This value was similar to those for the members of Psychroflexus (32.0-36.0 mol\%), but was lower than those for the members of Salegentibacter $(36 \cdot 8-38 \cdot 0 \mathrm{~mol} \%)$. The dominant cellular fatty acids of UST030701-324 ${ }^{\mathrm{T}}$ were i15:0, i15:0 3-OH, i16:0, i16: 03 $\mathrm{OH}$, i17:0 3-OH, summed feature 3 (comprising i15:0 2$\mathrm{OH}$ and/or $16: 1 \omega 7 c)$ and an unknown fatty acid with a carbon chain length equivalent to 13.6 (altogether representing $78.3 \%$ of the total) as determined using the Sherlock Microbial Identification System according to the manufacturer's protocol (Table 1). This fatty acid profile differed from those described for Psychroflexus and Salegentibacter by, for instance, the absence of $15: 0$ and the presence of i17: $1 \omega 9 \mathrm{c}$ and an unknown fatty acid (Table 1). MK-6 was the only respiratory quinone as determined using an HPLC method according to Collins (1994). Menaquinones extracted from Cellulophaga lytica (Johansen et al., 1999) and Pedobacter heparinus (Steyn et al., 1998) served as references for MK-6 and MK-7, respectively.

The phenotypic characteristics of UST030701-324 $4^{\mathrm{T}}$ are given in the species description and in Supplementary Tables S1 and S2 available in IJSEM Online. Anaerobic growth was examined in the Oxoid Anaerobic System. The requirement for $\mathrm{NaCl}$ was tested in a medium containing (per litre) $5 \mathrm{~g} \mathrm{MgCl}_{2}, 2 \mathrm{~g} \mathrm{MgSO}_{4}, 0.5 \mathrm{~g} \mathrm{CaCl}_{2}, 1 \mathrm{~g} \mathrm{KCl}, 5 \mathrm{~g}$ peptone and various amounts of $\mathrm{NaCl}$, adjusted to $\mathrm{pH} 7 \cdot 5$ using KOH (Isnansetyo \& Kamei, 2003). Cell morphology was examined using scanning electron microscopy (JEOL $7600 \mathrm{~F}$ ) according to the procedures in Neu et al. (2001) (see Supplementary Fig. S1). Reaction to Gram stain was determined using light microscopy according to Smibert \& Krieg (1994). Gliding motility was determined using phasecontrast light microscopy after growth on quarter-strength marine 2216 medium solidified with $1 \%$ agar according to Bowman (2000). Susceptibility to antibiotics was tested according to Acar (1980). Flexirubin-type pigment production and cellulose hydrolysis were determined according to Bowman (2000). Casein hydrolysis was determined according to Norris et al. (1985) and chitin and Tween 20, 40 and 80 hydrolysis was determined according to Baumann \& Baumann (1988). Spore formation, oxidase and catalase activities and the hydrolysis of agar, DNA and starch were tested according to Smibert \& Krieg (1994). Other enzyme activities, growth on carbon sources, acid production from carbon sources, nitrate reduction and the production of $\mathrm{H}_{2} \mathrm{~S}$, indole and acetoin were tested using the commercial systems API 20E, API 20NE, API 50CH and API ZYM (bioMérieux). Cells for inoculation to the API systems were suspended in sterile solution of seawater mix at $22 \%$ salinity (MacDonell et al., 1982).

Chemotaxonomic and phenotypic characteristics that distinguish UST030701-324 ${ }^{\mathrm{T}}$ from other genera of Flavobacteriaceae are given in Tables 1 and 2. UST030701-324 ${ }^{\mathrm{T}}$ differs from the members of Psychroflexus by (i) having a 
Table 1. Comparison of major cellular fatty acids of UST030701-324 ${ }^{\top}$ and members of Psychroflexus and Salegentibacter

Taxa: 1, strain UST030701-324 ${ }^{\mathrm{T}}$; 2, Psychroflexus gondwanensis; 3, Psychroflexus torquis; 4, Psychroflexus tropicus; 5, Salegentibacter holothuriorum; 6, Salegentibacter mishustinae; 7, Salegentibacter salegens. Values are percentages of total fatty acids; values for UST030701-324 ${ }^{\mathrm{T}}, P$. gondwanensis and $P$. torquis are means \pm SD. Growth conditions: column $1,30^{\circ} \mathrm{C}$ on marine agar $\left(5 \mathrm{~g}\right.$ peptone $1^{-1}, 3$ g yeast extract $1^{-1}$ in $0 \cdot 22-\mu \mathrm{m}$-filtered sea water) for $48 \mathrm{~h} ; 2-4,15^{\circ} \mathrm{C}$ on marine agar 2216 (duration of cultivation not given); 5 and $6,28^{\circ} \mathrm{C}$ on marine agar 2216 for $48 \mathrm{~h} ; 7,20^{\circ} \mathrm{C}$ on trypticase soy agar for $48 \mathrm{~h}$. Data for members of Psychroflexus and Salegentibacter are from Bowman et al. (1998), McCammon \& Bowman (2000), Donachie et al. (2004) and Nedashkovskaya et al. (2004, 2005b).

\begin{tabular}{|lccccccc|}
\hline Fatty acid & $\mathbf{1}$ & $\mathbf{2}$ & $\mathbf{3}$ & $\mathbf{4}$ & $\mathbf{5}$ & $\mathbf{6}$ & $\mathbf{7}$ \\
\hline Unknown $13 \cdot 6$ & $6 \cdot 1 \pm 1 \cdot 8$ & - & - & - & - & - & - \\
i1 $1: 0$ & $2 \cdot 1 \pm 0 \cdot 8$ & $4 \cdot 8 \pm 0 \cdot 8$ & $1 \cdot 0 \pm 0 \cdot 2$ & $2 \cdot 7$ & - & - & - \\
$15: 0$ & - & $1 \cdot 9 \pm 0 \cdot 8$ & $4 \cdot 2 \pm 0 \cdot 6$ & $0 \cdot 6$ & $9 \cdot 6$ & $6 \cdot 7$ & $4 \cdot 5$ \\
a15:0 & $3 \cdot 8 \pm 2 \cdot 3$ & $23 \cdot 0 \pm 2 \cdot 7$ & $35 \cdot 2 \pm 4 \cdot 4$ & $19 \cdot 3$ & - & $7 \cdot 9$ & $11 \cdot 6$ \\
i15:0 & $33 \cdot 1 \pm 6 \cdot 4$ & $2 \cdot 1 \pm 0 \cdot 5$ & $1 \cdot 1 \pm 0 \cdot 3$ & $16 \cdot 7$ & $26 \cdot 3$ & $7 \cdot 5$ & $23 \cdot 7$ \\
i15: 1 & - & - & - & - & $18 \cdot 2$ & $12 \cdot 3$ & - \\
a15: $1 \omega 10 c$ & - & $18 \cdot 4 \pm 2 \cdot 5$ & $16 \cdot 9 \pm 1 \cdot 8$ & $12 \cdot 9$ & - & - & - \\
i15: $1 \omega 10 c$ & - & $2 \cdot 2 \pm 1 \cdot 0$ & $0 \cdot 4 \pm 0 \cdot 4$ & $11 \cdot 8$ & - & - & $3 \cdot 8$ \\
i15:0 3-OH & $5 \cdot 4 \pm 3 \cdot 0$ & $0 \cdot 9 \pm 0 \cdot 7$ & $0 \cdot 3 \pm 0 \cdot 2$ & $2 \cdot 9$ & - & - & - \\
i15:0 2-OH & $7 \cdot 5 \pm 3 \cdot 6 *$ & - & - & - & $7 \cdot 9$ & $7 \cdot 9 *$ & - \\
$16: 1 \omega 7 c$ & & - & - & - & $10 \cdot 4$ & & $9 \cdot 4$ \\
i16:0 & $6 \cdot 8 \pm 0 \cdot 4$ & $10 \cdot 9 \pm 0 \cdot 3$ & $6 \cdot 0 \pm 1 \cdot 2$ & $3 \cdot 4$ & - & - & $7 \cdot 6$ \\
i16:0 3-OH & $5 \cdot 7 \pm 3 \cdot 1$ & $18 \cdot 5 \pm 1 \cdot 6$ & $15 \cdot 4 \pm 1 \cdot 0$ & $10 \cdot 1$ & - & - & $0 \cdot 3$ \\
$17: 1 \omega 6 c$ & $2 \cdot 2 \pm 0 \cdot 4$ & - & - & - & - & - & $1 \cdot 8$ \\
i17: $1 \omega 9 c$ & $3 \cdot 5 \pm 0 \cdot 8$ & - & - & - & - & - & - \\
a17:0 3-OH & - & $6 \cdot 6 \pm 0 \cdot 8$ & $10 \cdot 9 \pm 3 \cdot 4$ & - & - & - & 2 \\
i17:0 3-OH & $13 \cdot 7 \pm 5 \cdot 5$ & $0 \cdot 9 \pm 0 \cdot 4$ & $0 \cdot 2 \pm 0 \cdot 1$ & $10 \cdot 0$ & - & $8 \cdot 6$ & 3 \\
$18: 0$ & $2 \cdot 5 \pm 0 \cdot 0$ & $0 \cdot 2 \pm 0 \cdot 2$ & $0 \cdot 1 \pm 0 \cdot 1$ & - & - & - & - \\
& & & & & & &
\end{tabular}

${ }^{\star}$ Appeared as summed feature 3, comprising i15:0 2-OH and/or 16:1 $1 \omega 7 c$.

different fatty acid profile, (ii) the absence of filamentous cells, carbohydrate metabolism (except for sucrose) or $\alpha$ and $\beta$-glucosidase activities, (iii) being able to hydrolyse gelatin and (iv) being less halo- and psychrotolerant. UST030701-324 ${ }^{\mathrm{T}}$ differs from the members of Salegentibacter by (i) having an orange pigmentation and a different fatty acid profile, (ii) being less halo- and psychrotolerant, (iii) being able to produce acetoin and (iv) the absence of carbohydrate metabolism (except for sucrose) or $\beta$ galactosidase activity. Additionally, UST030701-324 ${ }^{\mathrm{T}}$ can be distinguished from other closely related genera by traits detailed in Table 2. Molecular evidence together with chemotaxonomic and phenotypic characteristics suggests that UST030701-324 ${ }^{\mathrm{T}}$ constitutes a novel genus within the family Flavobacteriaceae.

\section{Description of Nonlabens gen. nov.}

Nonlabens (Non.la'bens. L. part. non not; L. part. adj. labens gliding; N.L. part. adj. Nonlabens non-gliding).

Gram-negative, short rod, non-motile and not forming spores. Strictly aerobic. MK-6 was the only respiratory quinone. Flexirubin-type pigments are not produced.
Catalase- and oxidase-positive. The genus contains one species, Nonlabens tegetincola, which is the type species.

\section{Description of Nonlabens tegetincola sp. nov.}

Nonlabens tegetincola (te.get.in' col.a. L. n. teges -etis mat; L. n. incola an inhabitant; N.L. n. tegetincola mat-inhabitant, pertaining to its microbial mat habitat).

Description is as for the genus plus the following. Colonies on marine agar are orange in colour, circular, $2 \cdot 0-4 \cdot 0 \mathrm{~mm}$ in diameter, convex with smooth surfaces and entire translucent margins. No diffusible pigment. Growth occurs between $12 \cdot 0$ and $44 \cdot 0{ }^{\circ} \mathrm{C}\left(28 \cdot 0-36 \cdot 0{ }^{\circ} \mathrm{C}\right.$ optimum $), \mathrm{pH} 5 \cdot 0$ and $10 \cdot 0$ and $2 \cdot 0$ and $4 \cdot 0 \% \mathrm{NaCl}$. Susceptible to ampicillin, chloramphenicol, penicillin, streptomycin and tetracycline, but not to kanamycin. DNA $\mathrm{G}+\mathrm{C}$ content is $33.6 \mathrm{~mol} \%$ and the dominant fatty acids are $\mathrm{i} 15: 0, \mathrm{i} 15: 03-\mathrm{OH}, \mathrm{i} 16: 0$, i16:0 3-OH, i17:0 3-OH, summed feature 3 (comprising i15: 0 2-OH and/or $16: 1 \omega 7 c$ ) and an unknown fatty acid with a carbon chain length equivalent to $13 \cdot 6$ (altogether representing $78 \cdot 3 \%$ of the total). Produces acetoin, but not indole or $\mathrm{H}_{2} \mathrm{~S}$. Nitrate is not reduced. Hydrolyses DNA, gelatin, starch and Tweens 20, 40 and 80, but not agar, 
Table 2. Differentiation of strain UST030701-324 ${ }^{\top}$ from closely related genera

+, Positive; -, negative; ND, not determined; v, variable. Data for Psychroflexus, Salegentibacter, Winogradskyella, Psychroserpens, Gelidibacter and Formosa are from Bowman et al. (1997, 1998), McCammon \& Bowman (2000), Macián et al. (2002), Donachie et al. (2004), Ivanova et al. (2004), Nedashkovskaya et al. (2004, 2005a, b) and Lau et al. (2005).

\begin{tabular}{|c|c|c|c|c|c|c|c|}
\hline Characteristic & UST030701-324 ${ }^{\mathrm{T}}$ & Psychroflexus & Salegentibacter & Winogradskyella & Psychroserpens & Gelidibacter & Formosa \\
\hline \multicolumn{8}{|l|}{ Growth: } \\
\hline $\mathrm{NaCl}(\%)$ & $2 \cdot 0-4 \cdot 0$ & $0 \cdot 0-15 \cdot 0$ & $0 \cdot 0-20 \cdot 0$ & $1 \cdot 0-8 \cdot 0$ & $0 \cdot 4-1 \cdot 5 \times$ seawater & $2 \cdot 0-6 \cdot 0$ & $0 \cdot 0-6 \cdot 0$ \\
\hline Temperature $\left({ }^{\circ} \mathrm{C}\right)$ & $12 \cdot 0-44 \cdot 0$ & $-16 \cdot 0$ to $43 \cdot 0$ & $4 \cdot 0-36 \cdot 0$ & $4 \cdot 0-44 \cdot 0$ & $0 \cdot 0-15 \cdot 0$ & $0 \cdot 0-37 \cdot 0$ & $5 \cdot 0-37 \cdot 0$ \\
\hline Pigmentation & Orange & Orange & Yellow & Yellow & Yellow & Yellow & Yellow \\
\hline Cell shape & Rod & $\begin{array}{l}\text { Coccoid, rod, } \\
\text { filament }\end{array}$ & Rod & Rod & Rod, ring, helical & Rod & Rod \\
\hline Gliding motility & - & $\mathrm{V}$ & - & + & - & + & + \\
\hline $\mathrm{G}+\mathrm{C}$ content $(\mathrm{mol} \%)$ & $33 \cdot 6$ & $32 \cdot 0-36 \cdot 0$ & $36 \cdot 8-37 \cdot 5$ & $32 \cdot 8-36 \cdot 1$ & $27 \cdot 0-29 \cdot 0$ & $36 \cdot 0-40 \cdot 3$ & $34 \cdot 0-34 \cdot 4$ \\
\hline Gelatin hydrolysis & + & - & + & + & $\mathrm{V}$ & + & + \\
\hline Acetoin production & + & ND & - & $\mathrm{V}$ & - & - & ND \\
\hline Nitrate reduction & - & $\mathrm{V}$ & $\mathrm{V}$ & - & - & - & + \\
\hline $\begin{array}{l}\text { Metabolism of } \\
\text { carbohydrates } \\
\text { other than sucrose }\end{array}$ & - & + & + & + & + & + & + \\
\hline \multicolumn{8}{|l|}{ Enzyme activities } \\
\hline$\alpha$ - and $\beta$-Glucosidase & - & + & $\mathrm{ND}$ & $-{ }^{*}$ & ND & $\mathrm{ND}$ & $\mathrm{ND}$ \\
\hline$\beta$-Galactosidase & - & - & + & - & $\mathrm{v}$ & - & ND \\
\hline Oxidase & + & + & + & + & - & - & - \\
\hline
\end{tabular}

*No data for Winogradskyella epiphytica, Winogradskyella eximia or Winogradskyella thalassocola.

casein, cellulose or chitin. Acid phosphatase, alkaline phosphatase, $\alpha$-chymotrypsin, cystine arylamidase, leucine arylamidase, valine arylamidase, esterase (C4), esterase lipase (C8), lipase (C14), trypsin and naphthol-ASBI-phosphohydrolase activities are positive. $N$-acetyl- $\beta$ glucosaminidase, arginine dihydrolase, $\alpha$-fucosidase, $\alpha$ galactosidase, $\beta$-galactosidase, $\alpha$-glucosidase, $\beta$-glucosidase, $\beta$-glucuronidase, $\alpha$-mannosidase, lysine decarboxylase, ornithine decarboxylase, tryptophan deaminase and urease activities are negative. Except for acid production from sucrose, no growth or acid production is observed from the carbon sources included in the API $50 \mathrm{CH}$, API $20 \mathrm{E}$ and API $20 \mathrm{NE}$ test systems. Except for growth on complex media containing yeast extract and peptone, the carbon and nitrogen sources supporting the growth of Nonlabens tegetincola are hitherto not known.

The type strain is UST030701-324 ${ }^{\mathrm{T}}$ (=NRRL B$41136^{\mathrm{T}}=\mathrm{JCM} 12886^{\mathrm{T}}$ ), isolated from a microbial mat in an estuarine mangrove habitat in the Bahamas.

\section{Acknowledgements}

The authors thank Mr Ken Lau for the analysis of respiratory quinones and Professor Hans G. Trüper for assistance with the Latin etymology. This work was supported by the RGC grants HKUST6240/04M and CA04/05.Sc01 to P.-Y. Q. and a NSF Biological Oceanography Program grant (OCE-0095724) to J. R.P.

\section{References}

Acar, J. F. (1980). The disc susceptibility test. In Antibiotics in Laboratory and Medicine, pp. 24-54. Edited by V. Lorian. Baltimore: Williams \& Wilkins.

Baumann, P. \& Baumann, L. (1988). The marine gram-negative eubacteria: genera Photobacterium, Beneckea, Alteromonas, Pseudomonas and Alcaligenes. In The Prokaryotes, vol. 1, pp.1302-1331. Edited by M. P. Starr, H. Stolp, H. G. Trüper, A. Balows \& H. Schlegel. Berlin: Springer.

Bernardet, J. F., Segers, P., Vancanneyt, M., Berthe, F., Kersters, K. \& Vandamme, P. (1996). Cutting a Gordian knot: emended classification and description of the genus Flavobacterium, emended description of the family Flavobacteriaceae, and proposal of Flavobacterium hydatis nom. nov. (basonym, Cytophaga aquatilis Strohl and Tait 1978). Int J Syst Bacteriol 46, 128-148.

Bowman, J. P. (2000). Description of Cellulophaga algicola sp. nov., isolated from the surfaces of Antarctic algae, and reclassification of Cytophaga uliginosa (ZoBell and Upham 1944) Reichenbach 1989 as Cellulophaga uliginosa comb. nov. Int J Syst Evol Microbiol 50, 1861-1868.

Bowman, J. P., McCammon, S. A., Brown, J. L., Nichols, P. D. \& McMeekin, T. A. (1997). Psychroserpens burtonensis gen. nov., sp. nov., and Gelidibacter algens gen. nov., sp. nov., psychrophilic bacteria isolated from Antarctic lacustrine and sea ice habitats. Int J Syst Bacteriol 47, 670-677.

Bowman, J. P., McCammon, S. A., Lewis, T., Skerratt, J. H., Brown, J. L., Nichols, D. S. \& McMeekin, T. A. (1998). Psychroflexus torquis gen. nov., sp. nov., a psychrophilic species from Antarctic sea ice, and reclassification of Flavobacterium gondwanense (Dobson et al., 1993) as Psychroflexus gondwanense gen. nov., comb. nov. Microbiology 144, 1601-1609. 
Collins, M. D. (1994). Isoprenoid quinones. In Chemical Methods in Prokaryotic Systematics, pp. 265-310. Edited by M. Goodfellow \& A. G. O’Donnell. Chichester: Wiley.

Donachie, S. P., Bowman, J. P. \& Alam, M. (2004). Psychroflexus tropicus sp. nov., an obligately halophilic Cytophaga-FlavobacteriumBacteroides group bacterium from an Hawaiian hypersaline lake. Int J Syst Evol Microbiol 54, 935-940.

Isnansetyo, A. \& Kamei, Y. (2003). Pseudoalteromonas phenolica sp. nov., a novel marine bacterium that produces phenolic antimethicillin-resistant Staphylococcus aureus substances. Int J Syst Evol Microbiol 53, 583-588.

Ivanova, E. P., Alexeeva, Y. V., Flavier, S., Wright, J. P., Zhukova, N. V., Gorshkova, N. M., Mikhailov, V. V., Nicolau, D. V. \& Christen, R. (2004). Formosa algae gen. nov., sp. nov., a novel member of the family Flavobacteriaceae. Int J Syst Evol Microbiol 54, 705-711.

Johansen, J. E., Nielsen, P. \& Sjoholm, C. (1999). Description of Cellulophaga baltica gen. nov., sp. nov. and Cellulophaga fucicola gen. nov., sp. nov. and reclassification of [Cytophaga] lytica to Cellulophaga lytica gen. nov., comb. nov. Int J Syst Bacteriol 49, 1231-1240.

Lau, S. C. K., Tsoi, M. M. Y., Li, X., Plakhotnikova, I., Wu, M., Wong, P. K. \& Qian, P. Y. (2004). Loktanella hongkongensis sp. nov., a novel member of the $\alpha$-Proteobacteria originating from marine biofilms in Hong Kong waters. Int J Syst Evol Microbiol 54, 2281-2284.

Lau, S. C. K., Tsoi, M. M. Y., Li, X. \& 7 other authors (2005). Winogradskyella poriferorum sp. nov., a novel member of the family Flavobacteriaceae isolated from a sponge in the Bahamas. Int J Syst Evol Microbiol 55, 1589-1592.

Ludwig, W., Strunk, O., Westram, R. \& 29 other authors (2004). ARB: a software environment for sequence data. Nucleic Acids Res 32, 1363-1371.

MacDonell, M. T., Singleton, F. L. \& Hood, M. A. (1982). Diluent composition for use of API 20E characterizing marine and estuarine bacteria. Appl Environ Microbiol 44, 423-427.

Macián, M. C., Pujalte, M. J., Márquez, M. C., Ludwig, W., Ventosa, A., Garay, E. \& Schleifer, K. H. (2002). Gelidibacter mesophilus sp. nov., a novel marine bacterium in the family Flavobacteriaceae. Int J Syst Evol Microbiol 52, 1325-1329.
McCammon, S. A. \& Bowman, J. P. (2000). Taxonomy of Antarctic Flavobacterium species: description of Flavobacterium gillisiae sp. nov., Flavobacterium tegetincola sp. nov. and Flavobacterium xanthum sp. nov., nom. rev., and reclassification of [Flavobacterium] salegens as Salegentibacter salegens gen. nov., comb. nov. Int J Syst Evol Microbiol 50, 1055-1063.

Mesbah, M., Premachandran, U. \& Whitman, W. B. (1989). Precise measurement of the $\mathrm{G}+\mathrm{C}$ content of deoxyribonucleic acid by highperformance liquid chromatography. Int J Syst Bacteriol 39, 159-167.

Nedashkovskaya, O. I., Suzuki, M., Vancanneyt, M., Cleenwerck, I., Zhukova, N. V., Vysotskii, M. V., Mikhailov, V. V. \& Swings, J. (2004). Salegentibacter holothuriorum sp. nov. isolated from the edible holothurian Apostichopus japonicus. Int J Syst Evol Microbiol 54, 1107-1110.

Nedashkovskaya, O. I., Kim, S. B., Han, S. K. \& 9 other authors (2005a). Winogradskyella thalassicola gen. nov., sp. nov., Winogradskyella epiphytica sp. nov. and Winogradskyella eximia sp. nov., marine bacteria of the family Flavobacteriaceae. Int J Syst Evol Microbiol 55, 49-55.

Nedashkovskaya, O. I., Kim, S. B., Lysenko, A. M., Mikhailov, V. V., Bae, K. S. \& Kim, I. S. (2005b). Salegentibacter mishustinae sp. nov., isolated from the sea urchin Strongylocentrotus intermedius. Int J Syst Evol Microbiol 55, 235-238.

Neu, B., Voigt, A., Mitlohner, R. \& 7 other authors (2001). Biological cells as templates for hollow microcapsules. J Microencapsul 18, 385-395.

Norris, J. R., Ribbons, D. W. \& Varma, A. K. (editors) (1985). Methods in Microbiology, vol. 18. London: Academic Press.

Smibert, R. M. \& Krieg, N. R. (1994). Phenotypic characteristics. In Methods for General and Molecular Biology, pp. 607-654. Edited by P. Gerhardt, R. G. E. Murray, W. A. Wood \& N. R. Krieg. Washington, DC: American Society for Microbiology.

Steyn, P. L., Segers, P., Vancanneyt, M., Sandra, P., Kersters, K. \& Joubert, J. J. (1998). Classification of heparinolytic bacteria into a new genus, Pedobacter, comprising four species: Pedobacter heparinus comb. nov., Pedobacter piscium comb. nov., Pedobacter africanus sp. nov. and Pedobacter saltans sp. nov. Proposal of the family Sphingobacteriaceae fam. nov. Int J Syst Bacteriol 48, 165-177. 